\title{
The Pronunciation of English Fricatives in the Speech by a Non Native Speaker
}

\author{
Luh Gde Titah Madriyanthi Utama \\ English Department, Faculty of Arts, Udayana University \\ [Email:titahutama96@gmail.com]
}

\begin{abstract}
The title of this study is "The Pronunciation of English Fricatives in the Speech by a Non Native Speaker". The topic was chosen based on the fact that most of the nonEnglish speaking people are having difficulties with the pronunciation of the fricatives. Moreover, this study was also taking the unique characteristic of Balinese people in pronouncing the English fricative sounds which are delivered in a speech by the governor of Bali, I Made Mangku Pastika. There were two videos of his speech used in this study, the first was a formal speech from the speech of the tenth commemoration of Bali bombing tragedy, and the second speech was a non-formal speech at his interview event. This study identified the words with fricative sounds and their pronunciations according to Standard English, identified how the words are pronounced by the speaker, and identified problems that occurred in the pronunciation through spectrograms. The data were analyzed by using qualitative method with descriptive analysis technique. This study found various words with fricative sounds in both formal and non-formal speech. There were also some differentiations in the pronunciation of fricatives by the speaker, compared with in Standard English. The spectrogram analysis of the pronunciation found the exaggeration of the speaker in pronouncing the fricatives, both in his formal and non-formal speech.
\end{abstract}

Keywords: fricatives, pronunciation, frequency

Abstrak
Judul dari penelitian ini adalah "The Pronunciation of English Fricatives in the Speech
by a Non Native Speaker". Topik ini dipilih berdasarkan kesulitan yang dialami orang
non-Inggris saat melafalkan bunyi frikativ. Penelitian ini juga mengambil keunikan
pelafalan bunyi oleh orang Bali ketika mengucapkan bunyi frikativ yang dibawakan
dalam pidato oleh gubernur Bali, I Made Mangku Pastika. Terdapat dua video yang
digunakan dalam penelitian ini, yang pertama ialah sebuah pidato formal peringatan
sepuluh tahun bom Bali dan yang kedua ialah sebuah pidato non formal dalam sebuah
acara wawancara. Penelitian ini bertujuan untuk mengidentifikasi kata-kata dengan
bunyi frikativ dan pengucapannya sesuai bahasa Inggris Standar, mengidentifikasi
bagaimana bunyi tersebut diucapkan oleh pembicara, dan mengidentifikasi masalah
yang ada dalam pengucapannya melalui spekrogram. Data dianalisis menggunakan
metode kualitatif dengan teknik analisis deskriptif. Penelitian ini menemukan banyak
kata dengan bunyi frikativ dalam pidato formal dan non formal. Terdapat pula
perbedaan pengucapan bunyi frikativ oleh pembicara jika dibandingkan dengan bahasa


Inggris Standar. Analisis spektogram menunjukkan pengucapan bunyi frikativ yang dilebih-lebihkan dalam kedua pidato tersebut.

Kata kunci: frikativ, pengucapan, frekuensi

\section{Background of the Study}

According to Roach (2009:39), fricatives are consonants with the characteristic that air escapes through a narrow passage and makes a hissing sound. It is said that the fricatives is difficult in pronunciation and recognition for a foreign learner of English. English is categorized as a foreign language in Indonesia; and the language is learnt in both formal and informal education institutions, or by self-learning. In Bali, which is one of the well-known tourist destinations in Indonesia, the importance of English as a language has made a great impact on the people itself to learn the language. In this study, the fricatives are interesting topics to be taken based on the fact that most of the non-English speaking people are having difficulties with the pronunciation of the fricatives. Moreover, this study was also taking the unique characteristic of Balinese people in pronouncing the English fricatives. The object of this study was taken from the video of formal and non-formal speech, which was delivered by the governor of Bali, I Made Mangku Pastika. Like the other Balinese people, the Balinese accent can be found in his English speech from the video. His Balinese accent carried some characteristics and influenced his pronunciation of English fricatives.

\section{Problems of the Study}

a. What words contain fricatives sounds and their pronunciations according to Standard English found in the speech of I Made Mangku Pastika?

b. How the words are pronounced by the speaker I Made Mangku Pastika? c. What problems occur in the pronunciation by the speaker in pronouncing the words compared with the Standard English?

\section{Aims of the Study}

a. To identify the words that contain fricative sounds and their pronunciations according to Standard English found in the speech delivered I Made Mangku Pastika.

b. To identify how the words are pronounced by the speaker I Made Mangku Pastika.

c. To identify problems occurring in the pronunciation by the speaker in pronouncing the words compared with the Standard English.

\section{Research Method}

The research method is classified into four parts: data source, method and technique of collecting data, method and technique of analyzing data, and method and technique of presenting the analysis.

\subsection{Data Source}

The source of data in this study was taken from the speech videos presented by I Made Mangku Pastika. Two videos were used in this study. The first video was a speech delivered on the tenth $\left(10^{\text {th }}\right)$ commemoration of Bali Bombing Tragedy. The speech was presented in December 2010 in Garuda Wisnu Kencana (GWK) Cultural Park, Jimbaran, Badung. This video was used as an example of a formal speech from the speaker himself. The second video is a non-formal interview video. The participants of the video were a foreigner as an interviewer, and I Made Mangku Pastika as an interviewee. Those videos 
were chosen because they give the natural way of speaking from the speaker himself, especially in order to analyze the differentiation found in the pronunciation of English fricatives.

\subsection{Method and technique of collecting data}

The method used in collecting the data was observation method. The video was observed in order to analyze the pronunciation of the words that contain fricatives. After observing both of the videos, the words with fricative sounds were listed by note taking. Both of the videos were then converted into audio WAV files, and they were cut per word in certain pronunciation. The spectrogram of each pronunciation was analyzed by using a speech analyzer computer program.

\subsection{Method and technique of analyzing data}

The method used in analyzing the data was qualitative method with descriptive analysis. There were several steps in analyzing the data. The first step was watching and listening to both of the videos. The words that contain fricative sounds were listed and noted and they were written separately between the formal and informal speech video. After the words had been compiled, they were divided into several sections according to the classification of English fricatives as proposed by Peter Roach in his theory of phonology. The following step was transcribing all the words found into their phonetic transcription of Standard English by looking at the Oxford Advanced Dictionary.

The next step was transcribing the listed English fricative words based on the speaker's pronunciation. The pronunciation of the English fricatives for the Standard English was acquired by recording the pronunciation of the same words. It was retrieved from the online Oxford Dictionaries (https://www.oxforddictionaries.com). In acquiring the spectrogram of the pronunciation, the pronunciations were analyzed using a speech analyzer computer program. The images were used as the realizations of the pronunciation by the speaker. The differences between pronunciation of formal, informal, and Standard English speech were analyzed. The theory of spectrographic analysis by Peter Ladefoged was used in analyzing the spectrograms.

\subsection{Method and Technique of presenting analysis}

This study applied the two methods stated by Sudaryanto (1993:145), namely formal and informal method. The informal method applied in the presenting the analysis of the first and the second problem. It is the same as in analyzing the third problem, figures were presented. Meanwhile, the formal method was also used in this study.

\section{Results and discussions}

The analysis of the data can be written as follows.

\subsection{The Words with English Fricatives Found in the Speech by the Speaker}

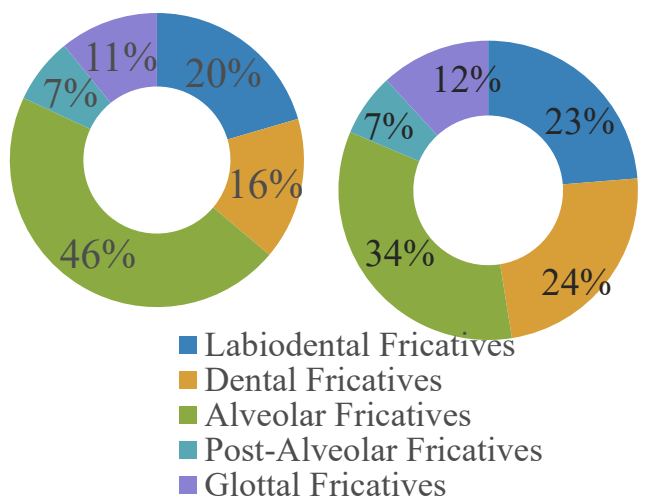

Figure 1. Words with English Fricatives Found in the Speech of the 10th Commemoration of Bali Bombing 
Tragedy (left), and in the speech of the speaker's interview event (right).

There are various words with English fricatives found in both formal and nonformal speech. From the data collected in both formal and non-formal speeches, the sounds analyzed were fricatives. The sounds that mostly occur were alveolar fricatives. The diagram on the left in Figure 1 shows that the majority of fricative words were found in the alveolar fricatives. It is followed by words found in the labiodental fricatives and dental fricatives. Meanwhile, the lesser amount of fricative words found in the post alveolar fricatives and dental fricatives. From the diagram on the right, it can be seen that the majority of words were found in the alveolar fricatives. Then it was followed by dental and labiodental fricatives. While the lesser amount of words were from glottal and post-alveolar fricatives.

5.2 The Pronunciation of the Fricatives by the Speaker

\begin{tabular}{|c|c|c|}
\hline $\begin{array}{l}\text { English } \\
\text { Fricatives }\end{array}$ & $\begin{array}{l}\text { Formal } \\
\text { Speech }\end{array}$ & $\begin{array}{c}\text { Non } \\
\text { Formal } \\
\text { Speech }\end{array}$ \\
\hline \multirow{6}{*}{$\begin{array}{l}\text { Labio- } \\
\text { dentals }\end{array}$} & $03: 47$ & \\
\hline & Face & \\
\hline & $\begin{array}{l}{[\text { feIs }]} \\
{[\text { feIs }]}\end{array}$ & $\begin{array}{c}01: 16 \\
\text { Forgive }\end{array}$ \\
\hline & $02: 23$ & $\begin{array}{l}{[\text { forgiv }]} \\
{\left[\text { fo' }^{\prime} \text { gIV }\right]}\end{array}$ \\
\hline & Give & \\
\hline & $\begin{array}{l}{\left[g_{I V}\right]} \\
{\left[g_{I V}\right]}\end{array}$ & \\
\hline & 01:32 & 01:39: \\
\hline Dentals & 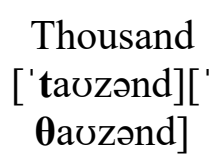 & $\begin{array}{l}\text { Northern } \\
\text { ['nortən] } \\
\text { ['nə:ðən] }\end{array}$ \\
\hline
\end{tabular}

Alveolars

$$
\text { 02:04 00:30 }
$$

Those Something

[ðpoz] ['s

[ðวठz] ['s $\mathrm{sm} \theta \mathrm{in}]$

01:24 01:34

Bless Relatives

$\begin{array}{ll}\text { [bles }] & \text { ['relətivs }] \\ \text { [bles }] & \text { ['relətivz }]\end{array}$

\begin{tabular}{|c|c|c|}
\hline & $\begin{array}{c}01: 15 \\
\text { Brothers } \\
\text { ['brıðərs][' } \\
\text { brıðəz] }\end{array}$ & $\begin{array}{l}00: 58 \\
\text { So } \\
{[\mathbf{s} ə \mho]} \\
{[\mathbf{s ə \mho}]}\end{array}$ \\
\hline $\begin{array}{l}\text { Post- } \\
\text { alveolars }\end{array}$ & $\begin{array}{c}02: 55 \\
\text { Shown } \\
{[\text { joon }]} \\
{[\text { Joon }]}\end{array}$ & $\begin{array}{c}01: 03 \\
\text { Nations } \\
\left.\text { ['ne } \int i ə n s\right] \\
\text { ['nerfonz] }\end{array}$ \\
\hline Glottals & $\begin{array}{c}\text { 01:35 } \\
\text { Behalf } \\
\text { [bI'ha:f] } \\
\text { [bi'ha:f] }\end{array}$ & $\begin{array}{c}\text { 01:10 } \\
\text { Handle } \\
\text { ['hændl] } \\
\text { ['hændl] }\end{array}$ \\
\hline
\end{tabular}

Table 1. The Pronunciation of English fricatives by the speaker in both speeches compared with Standard English pronunciation.

From the regular hearing, the speaker could pronounce the English fricatives correctly. However, there were still some mispronunciations in the pronunciation. There is a substitution of pronouncing / $\mathrm{z} /$ for $/ \mathrm{s} /$ sound in the alveolar fricatives. The problems found in the pronunciation of the non-formal speech with the same substitution of pronouncing $/ \mathrm{z} /$ for $/ \mathrm{s} /$ sound, and the substitution of $/ \theta /$ for $/ t /$. These show the characteristics of the speaker himself who tended to shift his fricatives pronunciation. 


\subsection{Problems in the Pronunciation by the Speaker}

This section analyzed the problems in the pronunciation by the speaker in pronouncing the words with English fricative sounds from both formal and non-formal speech. The analysis was done by comparing both the transcription by the speaker with Standard English, and it was followed by looking through the realization of the pronunciation which could be seen from the spectrograms. The analysis can be written as follows.

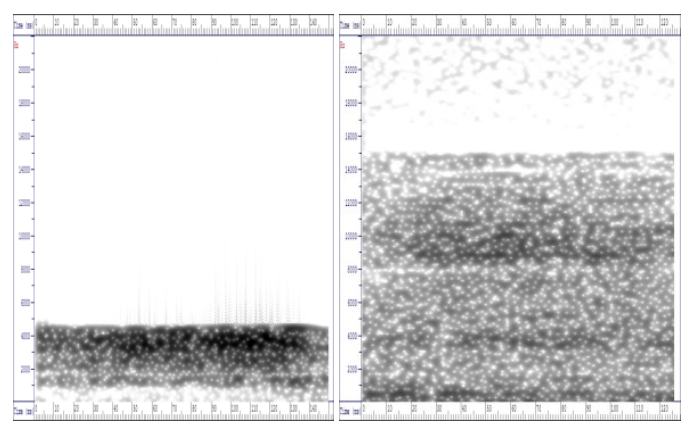

Figure 2. The spectrogram of [f] by the speaker (right) and in Standard English (left).

The difference between sound [f] produced by the speaker and in Standard English was in the frequency. In Figure 2 , the highest frequency of sound [f] sound was produced by the speaker. The frequency was about $15000 \mathrm{~Hz}$. While the frequency of sound [f] produced by a native speaker in the Standard English was $5000 \mathrm{~Hz}$. While in the pronunciation of $[\mathrm{v}]$ sounds, the highest frequency found in the speaker's pronunciation was around $8000 \mathrm{~Hz}$. The frequency found in Standard English was about $6000 \mathrm{~Hz}$. The high frequency in the spectrogram from the speaker means that he tended to give more power in pronouncing the fricatives. He was trying to personalize his tongue in pronouncing the word since the speaker is a well-educated person and he knows how to pronounce words in English correctly. The other reason which could affect his pronunciation was the mother tongue influence. As it is known that the speaker is a Balinese person. The phonological system of Balinese language is different from English. Here, the sounds [f] and [v] rarely occurred in the Balinese words, making the speaker try to personalize his pronunciation, and also tried to exaggerate his pronunciation which created high frequency in the spectrogram.

While in the Standard English, it was clear that the words were spoken by native speakers retrieved from the online Oxford Dictionaries. The speaker itself pronounced the sounds in a natural manner. There was no intentional force in pronouncing the sounds which made its frequency in the spectrogram is smaller.

\section{Conclusion}

Based on the description and the analysis in the chapter three, the following points of conclusion can be arrived at:

There were various words with English fricatives in both formal and non-formal speech. From the data collected in both formal and non-formal speeches, the sounds analyzed were fricatives.

In relation to the pronunciation of the words with fricatives by the speaker, several differences were found when comparing the pronunciation with Standard English taken from the English Advanced Learners' Dictionaries. There was a substitution of pronouncing / $\mathrm{z} /$ for sound $/ \mathrm{s} /$. The problems found in the pronunciation of the non-formal speech with the same substitution of pronouncing $/ \mathrm{z} /$ for sound $/ \mathrm{s} /$, and the substitution of $/ \theta /$ for $/ t /$. These showed the characteristics of the speaker himself who tended to shift his pronunciation of fricatives.

The analysis of the spectrograms between the speaker's pronunciation and in the 
Standard English pronunciation of the fricatives, there were the same characteristics found. It was on the frequency of the speaker's pronunciation which were higher than the frequency of the Standard English. It indicated the speaker who gave more power on his pronunciation of English fricatives and tended to exaggerate it to be closer to a native-like pronunciation. It could be stated that differentiation in the phonological system and the influence of the mother tongue could affect the speaker's pronunciation of English fricatives. There was a difference in the frequency of the speaker's pronunciation in his formal and non-formal speech. The frequency in his formal speech was higher than that in his non formal speech. It can be stated that the difference was the tense condition, in which formal speech was delivered in a formal situation with more tense condition than that in the non-formal speech. Therefore, his pronunciation in the formal speech produced higher frequency than the frequency of his pronunciation in the non-formal speech.

\section{Bibliography}

Andi-Pallawa, B., \&Fiptar Abdi Alam, A. (2013). A Comparative Analysis between English and Indonesian Phonological Systems. International Journal of English Language Education. Volume 1(3).

Anwar, M. Farid. (1987). Teori dan Praktek Pidato. Amin Surabaya, Surabaya.

Damayanti, Putu Meykha. (2008). English Pronunciation in Fricative Consonants by Balinese Shopkeepers at Kumbasari Market (Sarjana Sastra Thesis). Universitas Udayana, Denpasar.
Hornby, A S. (2010). Oxford Advanced Learner's Dictionary. Oxford University Press, London.

Kachru, Braj B. (1992). The Other Tongue: English Across Cultures. University of Illinois Press.

Ladefoged, Peter. (1993). A Course In Phonetics. Harcourt Brace Jovanovich College Publishers, United States of America.

Mnao, Adolfina K. (2015). Production of the English Dental Fricatives by the English Learners at Bali Star Academy (Sarjana Sastra Thesis).Universitas Udayana, Denpasar.

O’Hair, D., Kreps, G., \&Sparks, L. (2007). Handbook of Communication and Cancer Care. Hampton Press.

Ohata, Kota. (2004). Phonological Differences between Japanese and English: Several Potentially Problematic Areas of Prononciation for Japanese ESL/EFL Learners. The Asian EFL Journal. Volume 6.

Priatmoko, F. X. N. A. (2013). Critical Discourse Analysis of Susilo Bambang Yudhoyono's Speech (S.S. thesis). Dian Nuswantoro University, Semarang.

Roach, Peter. (2009). English Phonetics and Phonology: A Practical Course. Cambridge University Press, London.

Sudaryanto. (1993). Metode dan Aneka Tehnik Analisis Bahasa (Pengantar Penelitian Wahana Kebudayaan Secara Linguistik). Duta Wacana University Press, Yogyakarta. 
Tatarani, Ni Luh Putu Sukma. (2007). An Analysis of Pronunciation of Some English Phonemes Made by the Balinese Employees in Santika Beach Hotel (Sarjana Sastra Thesis). Universitas Udayana, Denpasar. 